\title{
On some Problems of Roman agrarian history.
}

\author{
By M. 0. B. Caspari.
}

(A). The post-Gracchan Land Laws.

(a) Chronology. - The only direct evidence which we possess for the dating of the land laws enacted in Rome as a wind-up to the reforming morement of the Gracchi is contained in a somewhat confused passage of Appian:

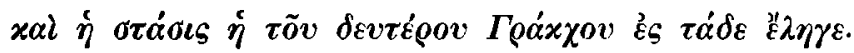

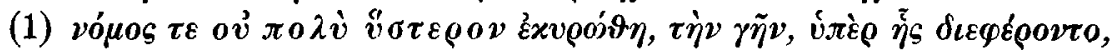

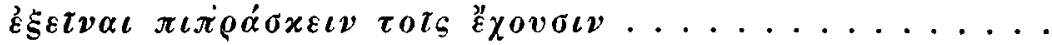

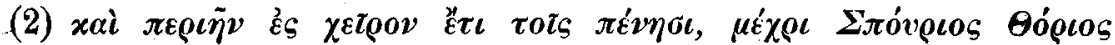

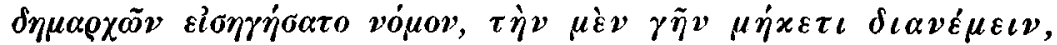

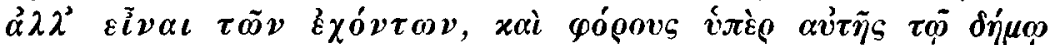

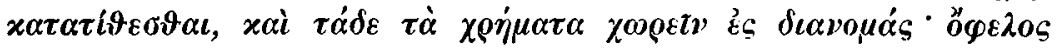

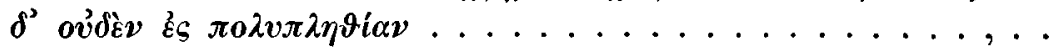

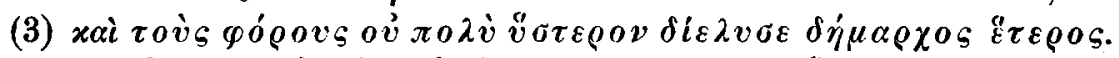

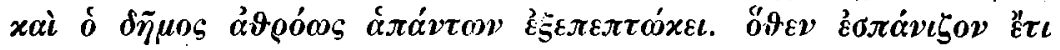

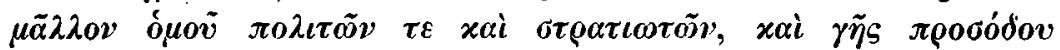

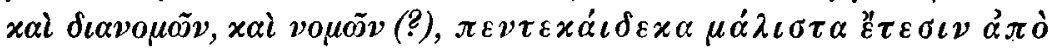

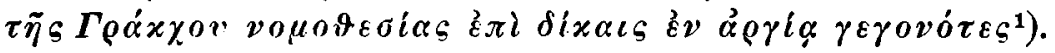

Of the first of these laws all that can be said is that it was passed soon after the death of Gaius Gracchus. The expression ov $\pi \circ \lambda \dot{v} v \sigma \tau \varepsilon \rho o v$, which is our only available mark of time, is too loose to permit of a definite assignation to any particular year ${ }^{2}$ ).

A clue to the date of the second law is supplied in the last words of the above quotation. These are usually taken to mean that the landcommission instituted in 133 B. C. by Tiberius Gracchus existed for

1) Bell. Civ. I ch. $27 \S 121-124$.

2) For a detailed refutation of theories which propose a more definite date, see Cardinali, Studi Graccani p. $196 \mathrm{n}$. 
15 years all told, and was then abolished ${ }^{1}$ ). Appian's second measure, which clearly implies the abrogation of Tiberius' commission, would thus belong to 118 or (counting inclusively) $119 \mathrm{~B}$. C.

But the 15 years mentioned in Appian's text are not made by him to cover the whole period of the commission's existence, but only those years during which its activities were suspended owing to delays in settling disputed claims ( Appian informs us that the year in which the distribution of land came to an end was $129 \mathrm{~B}$. C. (consulship of Tuditanus). If this is the time at which the commission entered upon its period of supended animation, its final extinction cannot have occurred before $114 \mathrm{~B}$. C., which is the date accepted by C. Neumann ${ }^{3}$ ) and Kornemann ${ }^{4}$ ).

Another point, however, remains to be considered. Did the commission remain continuously on the shelf to which it had been consigned in $129 \mathrm{~B}$. C., until it was finally swept into the rubbish heap? If such is the case, it must be assumed that Gaius Gracchus did not bring it again into operation. But the evidence in favour of Gaius having revived his brother's and law is too strong to be set aside ${ }^{5}$ ); and it follows with tolerable certainty that the land commission was revived at the same time and continued its work during the two years of Gaius' supremacy in Rome. It appears therefore that two further years should be allotted to its total span of life, its final abrogation thus falling in the year $112 \mathrm{~B}$. C.

In corroboration of this date it may be observed that in 112 B.C. some new regulations were undoubtedly made with regard to the ager publicus in Italy, and that these fresh enactments accorded some privi-

1) This is the interpretation put forward by Mommsen (Berichte üb. d. Verhandlungen $d$. Kgl. sächsischen Gesellschaft $d$. Wissenschaften, philol.-historische Klasse, vol. II (1850) pp. 89-95). The words of Appian's text would seem to admit of another version, viz. that the commission was suspended in the fifteenth year after Tiberius' legislation, i. e. in 118 B. C. It would be hard to say that the somewhat lax rules of late Greek grammar told against this translation any more than against Mommsen's. But Appian himself relates elsewhere (see next note) that the commission was reduced to inactivity as far back as $129 \mathrm{~B}$. C.

2) I ch. $19 \S 879-80$.

3) Geschichte Roms während des Verfalles der Republik pp. 265-6.

4) Klio, Beiheft I pp. 52-3.

5) Leaving aside those texts in which a confusion between Gains and his brother may be suspected, we find an unequivocal statement in Livy, Epit. LX: Gaius ... tulit ... legem agrariam, quam et frater eius tulerat. The frequent passages in the extant Lex Agraria (quoted in next note), in which certain Italian lands are mentioned as exempt from confiscation by a law of Gaius Gracchus; clearly imply that Gaius had renewed his brother's policy of land distribution, and such renewed distribution in turn implies the revival of the land commission. 
leges to the Latin and Italian tenants of these domains ${ }^{1}$ ). Although the exact nature of these facilities cannot be ascertained, the most probable inference is that inter alia they appropriated to various Latin and Italian corporations the territories which these had previously held on the precarious basis of possessio ${ }^{2}$ ). From this conclusion it is but a small step further to suppose that the same statute which conferred titles of ownership on the Latin; and Italian possessores also abolished the land commission of Tiberius. This body had no power to confiscate any estates except certain specified amounts of ager occupatorius. Of such available domains the greater part had certainly been seized by the commissioners long before 112 B. C., and it is unlikely that in this year there remained any large expanse of land liable to confiscation, save only those territories which were held by Latin and Italian corporations and had since 129 B. C. been virtually exempted from distribution for special reasons of federal politics ${ }^{3}$ ). To convert these estates into private property was therefore tantamount to abrogating the Gracchan commission, for this body would henceforth find its occupation gone. These is no evidence to show whether the law under discussion proceeded formally to abolish the commission-possibly its formal abrogation was never enacted-, but its contents appear sufficiently in accord with those of Appian's second measure to suggest the identification of the two. In this case Appian's second law certainly belongs to $112 \mathrm{~B}$. C.

The date of Appian's third law depends entirely on the question whether it should be identified with a statute extant in a well-known inscription of the former Bembine collection ${ }^{4}$ ), or whether it should be regarded as a separate measure. The former view is commended by the fact that the inscription contains that very provision, the abolition of rent on ager occupatorius ${ }^{5}$ ), which Appian makes the distinctive feature of his law; and the prevalent opinion is that the two measures should be regarded as one. But this identity has been denied by Walter ${ }^{6}$ ), on the ground

1) CIL I 200 ch. 29: item Latino peregrinoque, quibus M. Livio L. Calpurnio [consulibus] (i. e. 112 B. C.) licuit, sed sua fraude facere liceto. It is clear from the general context that the facilities here accorded are in connexion with the use of public land.

2) Greenidge, History of Rome p. 288.

3) Appian I. $19 \S 89-80$. This exemption threw the commission out of employment, a fact which proves that already in $129 \mathrm{~B}$. C. there remained little. land to confiscate save what was held by the Latins and Italians. Ed. Meyer has conjectured that the Latini peregrinique held absolutely the greater part of the ager occupatorius. (Kleine Schriften pp. 403-4.)

4) CIL I 200. - 5) Ch. 19.

6) Geschichte des romischen Rechts I p. 374 n. 69. 
that the inscription contains a great many additional clauses of which Appian makes no mention; and this same consideration has led Hardy ${ }^{1}$, the most recent editor of the inscription, to express some misgivings as to the correctness of the ordinary view.

Closer consideration of the extant statute will reveal that the discrepancy between it and Appian's law is more apparent than real. Of the residual clauses of the inscription some deal with non-Italian land, which does not come within the scope of Appian's narrative; others merely serve to confirm existing arrangements for the tenure of Italian estates and do not introduce any new features of importance. Furthermore, if it be true, in accordance with the above-mentioned theory ${ }^{2}$ ), that the appropriation of ager publicus to Latin and Italian communities had already been accomplished by a previous law in $112 \mathrm{~B}$. C., the clauses of the extant statute which deal with this same matter ${ }^{9}$ ) are, like so many others, a mere re-affirmation of existing regulations. In this case the paragraph concerning the abolition of rents is literally the only far-reaching innovation in the inscription with regard to land tenures in Italy. But however this may be, it remains true that the contents of Appian's third law, which no doubt are given by the historian in a highly summarised form, agree sufficiently well with the salient portions of our extant statute to justify our treating the two measures as one.

Now the date of the extant statute has been ascertained beyond all doubt as being 111 B. C. ${ }^{4}$ ). This is accordingly the year in which Appian's third law was passed ${ }^{5}$ ).

(b) Authorship.-The only thing that can be said for certain concerning the authorship of the laws now under discussion is that one of them was carried by a tribune named Sp. Thorius; but it remains a vexed question whether his measure was the second or the third in Appian's series 6). Appian himself, it is true, distinctly brings him into

1) Six Roman Laws p. 61 n. 17. - 2) Pp. 186. - 3) Chs. 31-2.

4) See Mommsen's commentary, $C I L$ I p. 76.

5) According to the present theory the second and third of Appian's laws were passed in consecutive years. This stands well in accord with Appian's statement that the third law was enacted ov $\pi 0 \lambda \dot{v}$ vorcoov after the third. This argument has been used by Kornemann in favour of dating the second law to 114 B. C. instead of 118 B. C.; but it carries still greater force if 112 B. C. is the year in question.

6) The former view has been put forward by Mommsen (CIL I p. 77), and adopted by Rudorff (Römische Rechtsgeschichte pp. 40, 211); Lange (Römische Altertiimer II pp. 581-2); Herzog (Geschichte und System der römischen Staatsverfassung I pp. 477-8); Kornemann (loc. cit.); Heitland (The Roman Republic II p. 326), and Hardy (op. cit. pp. 47-8); Niese (Grundriß der römischen Geschichte, 4th ed., p. 174) 


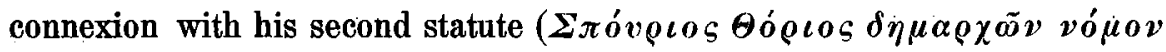

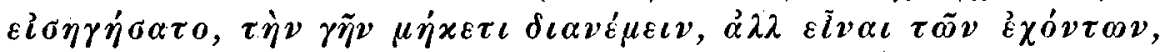
$\left.\left.x \alpha i \varphi o ́ \varrho o v \varsigma v \pi \dot{\varepsilon} \varrho \alpha \tilde{v} \tau \tilde{\eta} \varsigma \tau \tilde{\eta} \delta \eta^{\prime} \mu \varphi x \alpha \tau \alpha \tau i \vartheta \varepsilon \sigma \vartheta \alpha \iota\right)^{1}\right)$. But there is a passage in Cicero which apparently contradicts Appian's statement: $s p$. Thorius satis valuit in populari genere dicendi. Is qui agrum publicum vitiosa et inutili lege vectigali levavit ${ }^{2}$ ).

Not a few scholars have thought it possible to reconcile Cicero's words with Appian's by taking them to imply that 'Thorius relieved the public land of an improperly enacted and harmful law by [imposing] a rent', which agrees perfectly with all that Appian says. But, as has often been pointed out, this translation is very far-fetched, and does scant justice to Cicero's powers of expressing himself clearly. Furthermore, it raises an insoluble question with regard to the lex vitiosa et inutilis which Thorius ex hypothesi abolished. The only conceivable reference is to the land law of Tiberius Gracchus, fons et origo mali, by which the ager occupatorius was made liable to confiscation ${ }^{3}$ ). This measure might indeed be described from Cicero's point of view as inutilis, but on what grounds could it be called vitiosa, i. e. passed by an improper procedure? However much Tiberius may have dislocated the constitution, not one of his reforms was carried in contravention of legal propriety. His legislation was unimpeachable in form, and no exception could be taken at all events to the procedure by which his agrarian act was carried $\left.{ }^{4}\right)^{5}$ ).

inclines to the same view. The latter opinion was expressed by Rudorff in his earlier work, Das Ackergesetz des Sp.Thorius, and"is also maintained by Long (Decline of the Roman Republic I p. 354); Ihne (Römische Geschichte V p. 113 n. 3); C. Neumann (op. cit. pp. 265-6); Strachan-Davidson (Appian bk. I p. 31 n. 2); Greenidge (op. cit. p. 288 n. 2) and Maschke (Zur Theorie und Geschichte der römischen Agrargesetze pp. 87-8). - Daremberg-Saglio (s. v. Agrariae Leges) refrains from offering a definite decision, and Walter (loc. cit.) circumvents the difficulty by assuming that the Lex Thoria was distinct both from the second and from the third of Appian's measures. Walter's expedient is unsatisfactory, as he admits the similarity or identity of content between the Lex Thoria and Appian's third measure: plebiscita non sunt multiplicanda praeter necessitatem.

1) The MS. readings Bovéos and Bóotos have been generally rejected by modern critics and commentators in favour of $\theta$ óolos. This emendation is quite justified, as the forms Bóvolos and Bóplos are mere ghosts, being unknown to Roman nomenclature.

2) Brutus ch. 36 \$ 136. - 3) Hardy, op. cit. p. 47-8.

4) Though criticised and vilified by several ancient authors, Tiberius Gracchus is never accused by them of having violated the established forms of procedure in legislation.

5) The correctness of Tiberius' procedure is also admitted by modern critics - Mommsen (on the deposition of the tribune Octavius): 'sie ist besonders deshalb merkwurdig, weil hierbei alles in Form Rechtens vor sich ging, wie denn auch die Gültigkeit des Schlusses nirgends angefochten wird.' (Staatsrecht $\mathrm{I}^{3}$ 
Clearly then Cicero did not mean to say that Thorius relieved the ager publicus of Tiberius' land law; nor can any other agrarian statute previous to $111 \mathrm{~B}$. C. be found to which the words vitiosa et inutili lege could apply. Accordingly on grounds of content as well as of form the passage in Cicero cannot be regarded as an allusion to the second of Appian's measures.

Those scholars who would refer Cicero's words to the third law of Appian translate 'Thorius relieved the public land (i. e. the occupiers thereof) of a rent by means of an improperly passed and harmful law', the rent in question being that which was imposed by Appian's seeond

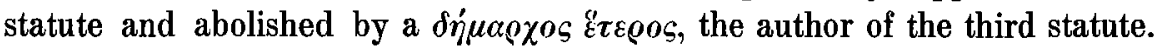

If this is what Cicero meant to say, he used an inexact expression, for the land relieved of taxation by the law of 111 . B. C. had been made private by Appian's second measure and should not in strictness be called ager publicus. But originally this estate had indeed been public land, and after its conversion into private property it was still burdened with dues to the public treasury, though these now took the form of a $\operatorname{tax}$ in lieu of a rent. We might go so far as to believe, without disrespect to Cicero, that he confused the tax with the rent: minima non curat pater patriae.

The present rendering of Cicero's text also has the disadvantage of creating a discrepancy between him and Appian. If Cicero is rightly regarded as identifying the Lex Thoria with the statute of $111 \mathrm{~B}$. C., Appian is plainly wróng in assigning it to some pretious year (118 or 114 or 112 B. C.). But this variance need hardly cause misgivings. Appian's mistakes as to names and dates are so numerous that one blunder more or less does not weigh in the scale ${ }^{1}$ ). Moreover if the second of his laws is dated, in accordance with the suggestion made above ${ }^{2}$ ), to

p. 630 n. 3); Pöhlmann: 'man kann nicht... in dem Sinne von einem sozialrevolutionären Vorgehen reden, daß Gracchus die Reform etwa durch einen Rechtsbruch durchgesetzt hätte.' (Berichte d. bayrischen Akademie, hist. Klasse, 1907, pp. 464-5.)

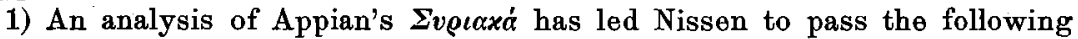
judgment: - 'ganz besonders hat Appian Namen und Zahlen in einer wahrhaft horrenden Weise entstellt.' (Untersuchungen üb, d. Quellen $d$. vierten $u$. fünften Dekade des Livius, p. 115.)

In the first two books of the Civil Wars the following errors may be noted:

I. 37 \&168: Mummius the destroyer of Corinth is exiled by the Quaestio Varia of 91 B. C.

I. ch. 40-42: Lucius Julius Caesar (consul in 90 B. C.) is repeatedly confused with Sextus (consul in 91 B. C.).

I. 120. 557: Appian fails to distingmish between M. and L. Lucullus.

II. 32. 124: C. Iulius Caesar's expedition to Britain is dated 50 B. C.

II. 111. 464: C. Cassius is confused with his brother Lucius.

2) P. 186. 
$112 \mathrm{~B}$. C., instead of 114 or $118 \mathrm{~B}$. C., the margin of error is reduced to one year only. On the whole, therefore, the objections against referring the lex Thoria to 111 B. C. seem less formidable than those which militate against an earlier date.

Confirmation of the theory now under consideration may be obtained in another passage of Cicero, which gives a further clue to the contents of the Lex Thoria: cum ageretur de agris publicis et lege Thoria et premeretur Lucilius ab iis, qui a pecore eius depasci agros publicos dicerent ${ }^{1}$ ). The charge here brought forward is that Lucilius' beasts cropped away all the public pasturage. Now there are some clauses in the statute of $111 \mathrm{~B}$. C. which distinctly assert the right of all and sundry to graze cattle up to a certain number on the common land, and consequently forbid the engrossing or monopolising of public pastures ${ }^{2}$ ). It is true that this connexion between the two texts has been pronounced illusory ${ }^{3}$ ); but further investigation may show that it ought after all to be accepted as quite valid. The law on which Lucilius' accusers took their stand was undoubtedly the Lex Thoria, else why should Cicero have gone out of his way to mention that measure? Now if the Lex Thoria is not the third of the acts in Appian's series, then it is the second. But the second law, so far as Appian describes it, contains nothing whatever concerning the use or misuse of public domains; and it is unlikely that it comprised, beside the provisions mentioned by Appian, a large assortment of other clauses on miscellaneous agrarian topics, for if such had been the case there would have been no subsequent need for a comprehensive regulating act like that of $111 \mathrm{~B}$. C. It follows that the Lex Thoria is probably identical with the statute of 111 B. C., which is the third in Appian's series.

If the statute to which Cicero alludes is that of the year $111 \mathrm{~B}$. C., it becomes possible to offer an explanation for the epithet vitiosa which he applies to it. Among the provisions of the Lex Agraria of $111 \mathrm{~B}$. C. are several paragraphs confirming a settlement of Roman or Italian emigrants on the territory of Carthage ${ }^{4}$ ). Now this site had been placed under a solemn curse after the destruction of the town by Scipio Aemilianus, and it was on the strength of this imprecation that the Lex Rubria of 122 B. C., by which Carthage was to be repeopled, was opposed and eventually rescinded ${ }^{5}$ ). But if the Lex Rubria was nefas, so was the

1) De Oratore $\Pi$ ch. 70 \$ 284. - 2) Chs. 24-26.

3) Walter, loc. cit. Hardy (Journal of Philology no. 63 p. 106) uses the passage in Cicero as evidence against the identification of the Lex Thoria with the statute of 111 B. C., on the ground that according to Cicero the Lex Thoria forbad the use of common pasture, whereas the act of $111 \mathrm{~B}$. C. permitted it. But all that is implied in Cicero's text is that the Lex Thoria prohibited the monopolisation of common land ('depasci').

4) Chs. 45, 59-69. - 5) Plutarch, C. Gracchus chs. 11, 13. 
law of $111 \mathrm{~B}$. C. in so far as it confirmed the Lex Rubria, and it is unlikely that the pontifices never entered a protest against it. In this case there would be a fair show of reason for calling the measure vitiosa, and Cicero's use of this word in reference to the Lex Thoria would cease to be mysterious.

If Appian s third law is appropriated to Thorius, the authorship of his second statute cannot be fixed with any approach to certainty. But if its date, as suggested in the present article, is $112 \mathrm{~B}$. C., it becomes tempting to bring the measure into connexion with M. Livius Drusus, consul of that year. Ten years previously Drusus had played a prominent part in overthrowing the authority of $\mathrm{C}$. Gracchus; the same man might very well have come forward as the leader of the campaign against the Gracchan land commission. Moreover the laws which Drusus promulgated as tribune in $122 \mathrm{~B} . \mathrm{C}^{1}$ ) are quite in keeping with the measure carried during his consulship. His tribunician bills are marked by a reckless profusion of the public revenues: they sacrifice sound finance to the necessities of political bribery. Similarly the act of 112 B. C. earmarked the rent on public lands for distribution to the Roman proletariate ${ }^{2}$ ). Whether this distribution was intended to be made in money or in corn, it can only be regarded as an attempt to appease the multitude on the principle which afterwards became so familiar to Roman statecraft, that the plebecula urbana was better pleased with doles of corn within Rome than with allotments of land in the 'inhospita tesqua' of Italy ${ }^{3}$ ). Again, the same concern for the Latins which distinguishes the law of 112 B. C: recurs in a seemingly extravagant form in a measure of the tribune Drusus which exempted Latin soldiers from the full rigour of Roman martial law. Whether Drusus was the formal author of the law passed during his consulship must remain a matter of complete uncertainty, but it may be tentatively conjectured that he was the real director of the movement which led to the extinction of the Gracehan land commission.

To sum up the previous discussion:-

(1) The number of agrarian measures passed between the death of C. Gracchus and 111 B. C. does not exceed three.

(2) Of the first post-Gracchan land law nothing definite can be said as to date and authorship.

1) Plutarch, C. Gracchus ch. 9.

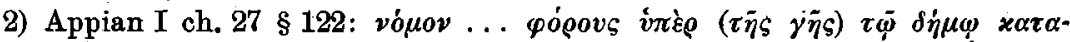

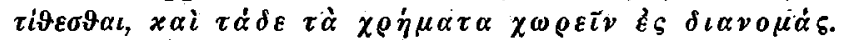

3) Cicero, De. Lege Agraria II ch. 27 \$ 71: vos vero, Quirites ..., retinete istam possessionem ... urbis ... ludorum, festorum dierum, ceterorum omnium commodorum, nisi forte mavultis ... in Sipontina siccitate aut in Salpinorum pestilentiae finibus. . . collocari. 
(3) The second law was most probably passed in $112 \mathrm{~B}$. C., and may tentativily be referred to the consul $M$. Livius Drusus.

(4) The third law is undoubtedly identical with the extant Lex Agraria of 111 B. C., and the balance of evidence is in favour of its being ascribed to Sp. Thorius.

(B) The Gracchan Land Acts and the Equites.

The opposition to the agrarian reforms of the Gracchi is usually regarded as coming solely from the ranks of the senatorial nobility, and the part played by the Ordo Equester in this conflict is seldom if ever discussed. Yet it is expressly stated by Livy that the land law of Tiberins was no less distastefal to the Equites than to the Senate 1). And this hostility on their part is no more than might have been expected, for it is probable that they stood to be penalised more heavily than the senators by Gracchus' proposals. Of the ager publicus which became liable to confiscation by Gracchus' law only a fraction can have belonged to the senatorial class. The Senate in the age of the Gracchi had a membership of about $300^{2}$ ). Out of these a certain number no doubt were not affected by Gracchus' threatened confiscations, as having no share in the ager publicus or too modest a portion to come within the scope of the new land law. On the other hand the amount of land assigned by the Gracchi after confiscation can hardly have been less than 1,000,000 iugera, and it may have been considerably more ${ }^{9}$ ).

If the whole of this acreage had been in the hands of, say, 250 senators, it would follow that each of these held at least 4000 iugera of public land, not to mention the 500-1000 iugera exempted from confiscation

1) Epit. LVIII: Ti. Sempronius Gracchus cum legem agrariam ferret adversus voluntatem senatus et equestris ordinis. See also Sallust, Bellum Iugurthinum ch. 42 \& 1 .

2) Willems, Le Sénat, pp. 30, 32, 303-357.

3) The number of Gracchan colonists is usually estimated at 75000, on the strength of the increased census returns of $125 \mathrm{~B}$. C. as compared with 130 B. C. Assuming that each colonist received 30 iugera, Nissen has calculated that the area of land allotted exceeded 2000000 ingera (Italische Landeskunde II p. 30). This pro capita measure is in excess of the amount usually allotted to Roman colonists, and the passage in the Lex Agraria of 111 B. C. from which it is deduced (ch. 14: sei quis . . . agri iugra non amplius XXX possidebit habebitue) hardly warrants so precise an inference. From Livy, Epit. LVIII it may further be gathered that the settlers received less than they expected. Nevertheless it is probable that Gracchus was generous in his assignments. Having made his allotments inalienable, he was bound to ensure that they should provide a sufficient margin of subsistence, and he must at any rate have awarded more than the 8-10 iugera which previous experience had proved sometimes to be inadequate to the needs of colonists. 
and such further territories as they might have owned or leased from the state in proper form. Now in the days of Cato the Elder the extent of a typical estate ranged from 100 to 240 iugera ${ }^{1}$ ). No doubt some domains, such as the great tracts of mountain pasture, considerably exceeded this limit, and in the era of the Gracchi there may have been an allround increase in the size of holdings. But after due allowance has been made for these facts it remains incredible that the senators of this period held on an average 4-5000 iugera or more of ager occupatorius. The land confiscated by the Gracchi cannot possibly have been concentrated in the hands of the senatorial class: a substantial amount thereof, perhaps the greater part, must have been held by the Equites ${ }^{2}$ ).

It must perhaps always remain an open question to what extent Gaius Gracchus was influenced by a desire to buy off the opposition of the Ordo Equester to his agrarian policy when he accorded them extravagant political privileges. But the possibility of this motive having contributed to his resolve is worth taking into account ${ }^{3}$ ).

\section{(C) The Encyclopaedia of Cassius Dionysius.}

This treatise, which in Varro's day had become a standard reference book on agriculture ${ }^{4}$, has given rise to some discussion as to its date and object.

Mahaffy, arguing that its composition was synchronous with the agrarian reforms of the Gracchi, has suggested that its purpose was to impart the most scientific methods of cultivation to the colonists whom C. Gracchus sent out to southern Italy ${ }^{5}$ ). Viewed in this light, Cassius' book was written in the interests of 'la petite culture'.

1) De re rustica chs. 10 and 11.

2) Similariy the engrossment of public lands during the $16^{\text {th }}$ and $18^{\text {th }}$ centuries which has helped to create the latifundia of modern England was not so much the work of the nobility as of the enriched traders and professional men. Pollard, England under Protector Somerset, pp. 204-5; Johnson, The Disappearance of the small Landowner, p. 120.

It would have been a marvel if the Equites of the later Roman Republic, whose commercial operations were nothing if not speculative, had not invested a substantial portion of their profits in real estate, which in those days was the only gilt-edged security.

3) The most sweeping of Gaius' projects, the enfranchisement of the Italian allies, is explicitly described by Appian (I. 21. 86.) as an expedient for silencing their clamour against his land reforms.

4) Varro, Res rustica I. 1. 10: his nobilitate Mago Carthaginiensis praeterit, poenica lingua qui res dispersas comprendit libris $X X I I X, q u o s$ Cassius Dionysius Uticensis vertit libris $X X$ ac graeca lingua Sextitio (v. 1. Sextio) praetori misit: in quae volumina de graecis libris... adiecit non pauca, et de $M a-$ gonis dempsit instar librorum VIII.

5) Hermathena, 1889, pp. 33-35. 
But the difficulties in the way of this theory are overwhelming. It fails to explain adequately why Cassius wrote his work in Greek, a fact which is all the more remarkable because his prototype, the Carthaginian Mago, had already been translated into Latin ${ }^{1}$ ). To say that in Tarentum and other towns of South Italy the trading classes used Greek as a lingua franca hardly meets the case. The colony at Tarentum was undoubtedly organised as a Roman township ${ }^{2}$ ), and those of its members who had any use for Cassius' book, being ex hypothesi cultivators of the soil, had no reason for abandoning their native Latin for a language used by traders and seafarers rather than by farmers.

Mahaffy further assumes that Cassius' patron was C. Sextius Calvinus, consul in 124 B. C., and that this worthy was in sympathy with the Gracchan land reforms. Neither of these conjectures can be proved, and the former is most improbable, as the MS authority in favour of the reading Sextio as against Sextilio is a vanishing quantity ${ }^{3}$ ).

It is evident that the attempt to connext Cassius' book with the agrarian movement of the Gracchi must be abandoned. On the other hand there is much to be said on behalf of a theory which ascribes his treatise to the carly years of the first century B. C. The 'praetor Sextilius' to whom Cassius dedicated his work is no doubt to be identified with the

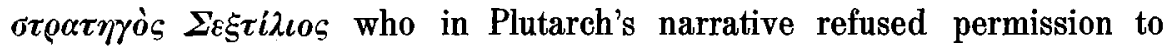
the exiled Marius to find a refuge in Africa ${ }^{4}$ ). The titulature used by Varro implies a date previous to $80 \mathrm{~B}$. C., for after the reorganisation of provincial government by Sulla Africa ceased to be administered by a praetor; and the simple citation of the name Sextilius without praenomen or cognomen indicates that only one 'praetor Sextilius' was to be found on the list of Africa's governors. It may therefore be inferred with some measure of confidence that the publication of Cassius' book fell in the time of Marius' exile, i. e. $88-7$ B. C.

If this is the date at which Cassius' magnum opus was issued, it may safely be presumed that it was planned in the earliest years of the

1) Varro, loc. cit.

2) The romanisation of the earlier Greek settlement at Tarentum may not have been completed until the first century B. C.; but the Gracchan colony must, like all Roman colonies, have been organised under Roman forms.

3) Neither Keil (Teubner, 1889), nor Schneider (Leipzig, 1794), who has a very full apparatus criticus, mentions the reading Sextio.

4) Plutarch, Marius, ch. 40. See Pauly-Wissowa, s. v. Cassius (no. 42); and Susemihl, Geschichte der griechischen Literatur in der Alexandrinerzeit I p. 830 n. 6 .

The reading $\Sigma \varepsilon \xi \tau i \lambda \iota s$ in Plutarch's text, which has been impugned by Mahaffy on the strength of a variant $\Sigma \xi \xi \tau \iota \varsigma$ in the corresponding passage of Appian (Bell. Civ. I ch. 62 \$279), has since been confirmed by numismatic evidence. See Viereck's edition of Appian (Teubner, 1905), in which $\Sigma \varepsilon^{\prime} \xi \tau / o s$ is emended into $\Sigma \varepsilon \xi \sigma \tau i \lambda \iota s$. 
first century B. C., for an encyclopaedia of 20 volumes would of course take some considerable time to complete. Now the opening years of the first century B. C. were a period of unusual peacefulness for the Roman empire, during which no further conquests were being projected nor any attacks upon existing possessions expected ${ }^{1}$ ). The time was accordingly a most suitable one for the development of industries and the scientific improvement of land. In England the classic period of progress in agriculture befell in the tranquil years that followed upon the peace of Utrecht. A similar opportunity for raising the value of their land by systematic cultivation presented itself to the Romans in the first decade of the first century B. C., and it would be surprising if during these years the need of a more comprehensive knowledge of scientific procedure in exploiting the land had not been felt. It was probably in answer to this demand for an up-to-date manual of agriculture that Cassius composed his 'Compleat .Farmer'.

The question remains, for what class of cultivators did Cassius write? We know nothing about the special agrarian interests of his patron; but the form and contents alike of his book should leave no doubt as to its destination. The fact of its being written in Greek clearly proves that it was not intended for the profanum vulgus of small peasants, but for a select circle of landowners who perhaps affected a foreign tongue for their own daily use, as was the fashion among some aristocrats of Sulla's time, and probably kept bailiffs of Greek extraction on their estates ${ }^{2}$ ). The contents of the treatise point to a similar conclusion. An important section thereof dealt with the organisation of servile labour in large gangs recruited from all the four corners of the earth ${ }^{3}$ ). Clearly this kind of literature was of no use save to capitalists who had an abundance of money to invest in an instrumentum vocale. It is also noticeable that Cassius supplemented the treatise of Mago out of Greek monographs, which tended to specialise on arboriculture ${ }^{4}$ ). From this it may be gathered that Cassius' book discussed this branch of the industry at some length: at all events it is

1) This latter point is proved by the woeful state of unpreparedness in which the Romans allowed themselves to be caught at the outbreak of the Social and Mithridatic Wars.

2) Slaves of Greek extraction were common enough in Italy at the beginning of the first century B. C., as is proved by the famous retort of king Nicomedes to the Senate's requisition of Bithynian troops in 104 B. C. (Diodorus 36, 3), and by the prevalence of Greek-speaking leaders in the Sicilian slave wars of 135-1 B. C. and 103-99 B. C. The same Greeks who were the natural leaders in a servile revolt would also be best qualified by their gifts of character and intelligence to act as overseers of an estate in times of peace.

3) Varro I. $17 \$ 3-7$.

4) See the list of writers in Susemihl I p. 829 sqq. 
certain that garden cultivation was taken up with great zest by the Italian landowners of his and the subsequent age ${ }^{1}$ ). But orchard land, though highly profitable in the long run, required a heavy outlay on stock, while on the other hand it needed a comparatively slight expenditure of human labour ${ }^{2}$ ). The conditions of this industry were therefore such as would favour an investor possessing large assets of money, and would tell against a small peasant whose chief capital lay in the strength and skill of his own body. The evidence thus appears all in favour of regarding Cassius as writing, like his predecessor Mago, in the interests of the large proprietor, and not as being concerned with the revival of the peasant industries which C. Gracchus had befriended in the previous generation.

\section{[Appendix.]}

After completion of the above article the present author had his attention drawn to Cardinali's recently published Studi Graccani. He is pleased to find himself in substantial accord with this learned and lucid treatise, but feels obliged to differ from its author on one or two particular points.

(1) As to the date of Appian's second law, Cardinali reverts to the

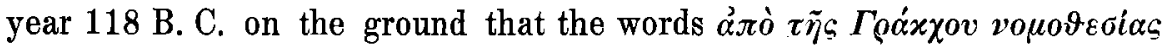
inexorably declare 133 B. C. as the terminus from which Appian's interval of 15 years must be measured (p. 198 n.). In so doing he is driven to assume that Appian in writing the above passage imagined the litigation consequent upon Tib. Gracchus' law to have begun as far back as $133 \mathrm{~B}$. C.

1) Varro I. 2. 6: non arboribus consita Italia, ut tota pomarium videatur?

2) Columella (Res Rustica, III. 3.8) estimates that in a properly equipped vineyard the cost of the vines and other material would amount to 2000 sesterces per iugerum, whereas the land itself could be bought at one half of that rate.

Cato (De re rustica, ch. 11) reckons that 16 men would be needed for 100 iugera of vine-land, which therefore would require the same expenditure of labour as was bestowed upon plough land in Columella's day (Weber, Die römische Agrargeschichte, p. 228). But the cultivation of cereals at the time when Columella wrote was a neglected art and probably required but a minimum expenditure of labour. In Cassius' days it seems likely that vine plantations were more economical of labour than corn land.

Whatever may hold true of viticulture, it is certain that olive orchards called for a comparatively slight outlay of labour. Cato (ch. 10) makes out that 13 men would suffice to cultivate 240 iugera.

It must also be borne in mind that vines and olives are not immediately remunerative. In the Lex Manciana (Bruns, Fontes Iuris Romani, $7^{\text {th }}$ ed., pp. 297-8) cultivators of vineyards were exempted from paying rent for 5 years and cultivators of olive-groves for 10 years. The latter of these exemptions was none too lenient, as olives take some $20-40$ years to mature completely. This deferment of profits might matter little to the lord of a latifundium; to a small cultivator it would generally have been ruinous. 
But in an adjacent passage (ch. 19) Appian states expressly that the impasse arising from the judicial delays did not occur until $129 \mathrm{~B}$. C. It is hardly credible that a few chapters lower down he had already forgotten this fact, on which in ch. 19 he lays considerable stress. On the other hand there seems no insuperable objection to taking the words

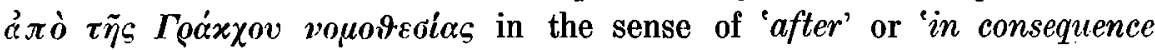
of', not necessarily 'since Gracchus' legislation'.

(2) The present author is loth to assume the reading Bóocos in the passage relating to Appian's second law as correct. But this is a point of no consequence. Even if it be assumed, as in the above article, that Appian's second law was passed in $112 \mathrm{~B}$. C. at the instigation of Livius Drusus, there is no reason why the formal proposer of this measure should not have borne the name of Borius.

(3) In estimating the amount of ager publicus redeemed by the Gracchan land law Cardinali refuses to draw any conclusions from the increase of the census between the years 131 and 125 B. C. (p. 179 sqq.). Were this scepticism justified, the computations made under section $B$ of the above article would be impaired, though not necessarily overthrown.

But Cardinali's reasoning is open to several objections.

(a) The theory that the proletarii of Rome were included in the census of republican times is by no means beyond the reach of controversy. It conflicts with the definitions of Fabius Pictor and Polybius,

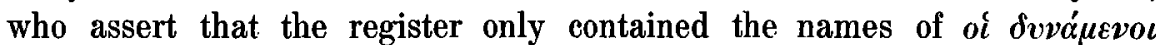

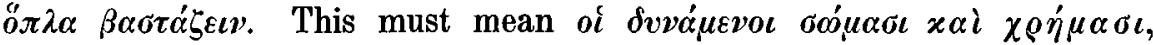
as it is well known that the Roman army previous to the days of Marius did not contain proletarii. The use of the term 'capite censi' is no sufficient argument against the statements of Pictor and Polybius. It is only employed by writers of imperial times (Pauly-Wissowa, s. v.), who may have been misled by the alteration in the basis of the census as reformed by Augustus.

(b) On no hypothesis save that of an increase in the number of holdings by Roman peasants can the rise of the census figures between 131 and 125 B. C. be explained. The expedient used by Beloch in his Bevölkerungslehre, viz. that the figures for $125 \mathrm{~B}$. C. as given in Livy's epitome, contain one cipher too much, conflicts with the sound doctrine which he lays down in his Italischer Bund (p. 58) that ciphers may. easily be omitted by copyists - this has undoubtedly occurred in the case of our extant census returns -, but will not readily be interpolated. Moreover the census return for $125 \mathrm{~B}$. C. again gives a much higher total than that of $131 \mathrm{~B}$. C., and there is no adequate reason for doubting its authenticity. 
198 M. O. B. Caspari, On some Problems of Roman agrarian history.

As to the return for $131 \mathrm{~B}$. C. showing a decrease as compared with that of $135 \mathrm{~B}$. C., it is not to be expected that the actual repopulation of the ager Romanus began immediately after the enactment of Tib. Gracchus' law. The preliminary business of ascertaining and delimiting the land available for distribution may well have occupied a year or so, in which case the new allotment-holders could not have taken possession of their farms until $131 \mathrm{~B}$. C. or even later.

(d) Although the persons endowed by Gracchus' land law had to pay a quit-rent and therefore were not proprietors optimo iure, it does not follow that they remained proletarii. Whatever their precise juristic position, economically they had become sufficiently wealthy to be available for military service. Moreover, since the very purpose of Gracchus' law was to increase the effective fighting force of Rome, it would have been a marvel if the new peasantry had been enrolled among the proletarii and had thus remained exempt from conscription.

London. 